\title{
On the Influence of Campus Culture on the Innovation-oriented Talents Cultivation
}

\author{
Lieming Fang ${ }^{1, a}$, Weiran Zhang ${ }^{2, b, *}$ and Xingyu Liü,c \\ ${ }^{1}$ Shandong Youth University of Political Science, Jinan, China \\ 2,3Beijing Institute of Petrochemical Technology, Beijing, China \\ afanglieming@126.com, bzhangweiran@bipt.edu.cn, c1091685911@qq.com \\ *The corresponding author
}

Keywords: Campus culture; Innovation-Oriented talents cultivation; Influence

\begin{abstract}
Innovation, a unique cognitive ability and practical ability exclusively possessed by human beings, is an inexhaustible motive force for promoting national progress and social development. The cultivation of innovative talents contributes to the prosperity of a country. Campus culture being the soul of the campus, the development of which is conducive to fostering a positive campus culture environment, better functioning of colleges and universities, training of innovative talents, and meeting the requirements of the country's social and economic development.
\end{abstract}

\section{Introduction}

Colleges and universities are important parts of the national and local innovation system, the base of independent innovation, and the driving force for social and economic development. Innovative talent training is the major task of colleges and universities. Being the soul of the campus, campus culture exerts great influence on innovative talents cultivation.

\section{The Characteristics of Innovative Talents}

Innovative talents refer to high-quality personnel with innovative spirit, innovative thinking and practical ability. They generally possess the following characteristics: strong curiosity and desire for knowledge; good self-learning and exploration ability; extensive and solid knowledge in certain field or aspect with high professional level; good moral cultivation and team-work spirit; sound body capable of undertaking hard work. Innovative talents also have a strong sense of mission and keen insight, a willingness to persevere, cooperate with others and keep pace with the times; having a strong learning ability, daring to be first, and being able to creatively apply what they have learnt to scientific research.

\section{The Concept of Campus Culture and Its Functions}

\section{The concept of campus culture}

Campus culture refers to the values, school ideas, group awareness, and behavioral norms formed by the school through long-term development and accumulation. Campus culture is a culture shared by a group which mainly consists of four elements: spiritual culture, institutional culture, material culture and behavioral culture.

First, spiritual culture, such as school philosophy, spirit advocated, educational philosophy, etc.. Spiritual culture is the core of campus culture.

Second, institutional culture, such as teaching management systems, behavioral norms, rules and regulations, performance evaluation methods and so on.

Third, material culture, such as the construction of teaching infrastructure, library book collection, sports facilities, multimedia equipments, green area, style of buildings and so on.

Fourth, behavioral culture, such as teachers' teaching behavior, organizing extracurricular activities, conducting research and social practice. 


\section{The functions of campus culture}

Campus culture can not only uplift the mind and the spirit of teachers and students, regulate their behaviors, but also strengthen their identity as members of schools, help them identify with the university's goal and regulations, and evoke their sense of mission, team spirit and group awareness. Campus culture also plays an imperceptible educational role for students.

(1) Guiding function

The so-called guiding function is to guide the school's leaders, teachers and students. The guiding function of campus culture is manifested in the following two aspects: (1) the guidance of management philosophy and values, which affects school's educational philosophy and educational policy; (2) the guidance of school goal, which affects the school's vision, school-running features, improves the competitiveness of the school through setting of goals.

\section{(2) Constraint function}

The constraint function of organizational culture is mainly achieved by perfecting management system and ethics. Sound regulations and moral norms play a normative role in thoughts, words and deeds of teachers and students. When teachers and students' thoughts, words and deeds do not meet the requirements of institutional rules and regulations, they will self-regulate and self-correct.

(3) Uniting function

Campus culture is an invisible force that guides the thinking style, life attitude, psychological taste and behavior of teachers and students. Teachers and students will unconsciously think and act in accordance with the school's values. Thus, campus culture inspires the teachers and students to work together toward the goals and achieve the desired results.

(4) Incentive function

Positive campus culture encourages teachers and students to forge ahead, not afraid of difficulties, pursue excellence, and strive to complete the tasks. Under the influence of campus culture, the teachers and students would develop a sense of responsibility and honor, work hard and constantly make accomplishments and achieve the school's strategic goals.

\section{The Impact of College Campus Culture on the Cultivation of Innovative Talents}

\section{The influence of campus spiritual culture on the cultivation of innovative talents}

Innovative education is an educational concept that meets the needs of higher education and economic and social development. It is also an educational model that integrates innovative education into the whole process of talent cultivation. The spiritual culture of the campus is a deep-level culture, which is reflected in the university spirit, school philosophy and school motto. It is the core and soul of the university campus culture. Positive campus culture activities can help students form a correct world view, life outlook, values, and shape a healthy personality. The innovation of talent training mode is inseparable from the renewal of ideas. Open, advanced and scientific concepts exert positive and dynamic influence on the cultivation of talents in colleges and universities. In the process of cultivating innovative entrepreneurial talents and contributing to an innovative country, colleges and universities should update their educational concepts and attach importance to the spreading of innovative talents training, making innovative education an educational concept, a school-running concept and put it into action. Efforts should be made to cultivate students' diligent, rigorous, truth-seeking, practical and innovative spirit, develop their unique thinking mode, and provide a good academic atmosphere and offer spiritual guidance for the cultivation of innovative talents.

\section{The influence of campus institutional culture on the cultivation of innovative talents}

The campus institutional culture consists of school teaching system, management system and moral values. The teaching rules and regulations have a more direct impact on the innovative talent training in that they influence the carrying-out of disciplines, teaching methods reform, setting of goals and modes of talent training. The discipline construction is one of the basic tasks of colleges and universities as well as an important index of the quality of school-running and personnel training. We should reform the traditional disciplines, develop feature specialties, cultivate innovative talents, and form a professional setting and adjustment mechanism that actively adapts to 
the needs of economic and social development. The key to develop a teaching plan or training program that matches the objective of cultivating innovative talents is to reform the traditional teaching methods, adopt flexible teaching methods, select good teaching materials and develop teaching resources. Teaching management system, including teachers' performance appraisal system, salary system, and effective incentive system, has a significant impact on teachers and the cultivation of innovative talents. We should strengthen the professional ideals and professional ethics of teachers, enhance their sense of responsibility, and guide them to shoulder the glorious duties of "nurturing students with morality" and make unremitting efforts to cultivate innovative talents.

\section{The influence of campus material culture on the cultivation of innovative talents}

The material culture of college campus is composed of the natural environment, layout, architecture style and implications of the campus. Material culture is an external manifestation of a special spiritual culture, which is embodied in the feelings and circumstances. Undoubtedly, beautiful natural environment, openness, harmony with society, coexistence of different architectural styles and the values embodied in the school buildings leave subtle influence on the cultivation of innovative talents. With more and more information in modern society and transmission and information updating getting faster and faster, students' knowledge updating and information exchange speed up thanks to the internet. And their thinking ability and adaptability is also improved. A beautiful campus and good environment are conducive to the study and life of college students and the formation of tolerance character. Therefore, the construction of material campus culture is indispensable for cultivation of innovative spirit.

The impact of campus behavioral culture on the cultivation of innovative talents

A very important aspect of campus culture development is to put it into action. Behavioral culture is the individual or group behavior in the daily teaching and learning environment, which is the external manifestation of campus culture. For example, the teachers' words and deeds exert impact on the cultivation of innovative talents. The innovative thinking and innovative spirit of teachers in the teaching process also leave subtle influence on students. Flexible and diverse campus cultural activities, such as extracurricular activities, scientific research and social practice, are beneficial to students' pursuit of deeper knowledge, development of multi-faceted talent and innovative ability, constantly inspiring students to take part in various practical activities, stimulating students' innovative consciousness and innovative thinking without fearing failure, training their ability to deal with problems independently and creatively, and strengthening their sense of competition and enterprising spirit.

\section{Conclusion}

Since campus culture plays an important role in the cultivation of innovative talents, colleges and universities must improve campus culture from four aspects: material culture, spiritual culture, institutional culture and behavioral culture. Meanwhile, campus culture should be kept up with the times to promote the sustainable development of colleges and universities and help nurture innovative talents who are urgently needed for social and economic development.

\section{Acknowledgements}

The paper is funded by the following projects: 2013 Shandong Province-level University Great Course---"Labor Economics" (course No. 2013 BK386);

2017 Overseas Study Program Funded by Shandong Provincial Government; 2016 Humanities and Social Sciences Research Program of the Universities of Shandong (Ideology and Politics)---"Research on Promoting Campus Culture in Newly Established Universities---Aiming at Innovative Talents Cultivation" (J16YB54); On the Construction and Usage of College English Mobile Network Resources (2018J00107).

\section{Reference}


[1] Wang Qinglin. Thoughts on the Mode of Innovative Applied Undergraduate Talents Training[J] .University Teaching in China. 2013 (6) : 20-23

[2] Fan Jixuan. Research on the Cultivation of Applied Innovative Talents in Newly Established Universities---Based on the Theory of University Organization Structure[J]. Journal of Yellow River University of Science and Technology. 2014 (3):107-111

[3] Che Rushan. Analysis on the Concept of Applied Innovation Talents[J]. University Education Management. 2015(1): 81-85

[4] Chen Lanlan. On the Role of Ideological and Political Education in the Cultivation of University Campus Culture[J] . Journal of the Party School of Jinan Municipal Committee of the Communist Party of China. 2015(2): 115-117

[5] Yan Liguang. Research on the Influence of University Campus Culture on the Communist Party Work [J] .Heilongjiang Higher Education Research. 2015(3): 108-110

[6] He Genhai. On the Innovative and Entrepreneurial Talents Training in Newly-built Universities[J]. China Higher Education. 2011(13): 46-48 